Fall 2016

\title{
Marketing as a Means to Transformative Social Conflict Resolution: Lessons from Transitioning War Economies and the Colombian Coffee Marketing System
}

\author{
Andres Barrios \\ Kristine de Valck \\ Clifford J. Shultz \\ Loyola University Chicago, cshultz@luc.edu \\ Olivier Sibai \\ Katharina C. Husemann

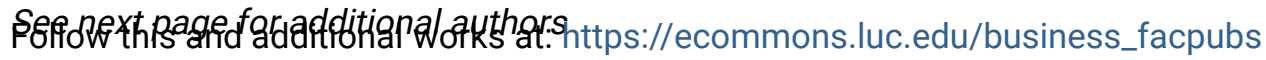 \\ Part of the Business Commons
}

\section{Recommended Citation}

Barrios, Andres; Valck, Kristine de; Shultz, Clifford J.; Sibai, Olivier; Husemann, Katharina C.; MaxwellSmith, Matthew; and Luedicke, Marius K.. Marketing as a Means to Transformative Social Conflict Resolution: Lessons from Transitioning War Economies and the Colombian Coffee Marketing System. Journal of Public Policy \& Marketing, 35, 2: 185-197, 2016. Retrieved from Loyola eCommons, School of Business: Faculty Publications and Other Works, http://dx.doi.org/1509/jppm.15.151

This Article is brought to you for free and open access by the Faculty Publications and Other Works by Department at Loyola eCommons. It has been accepted for inclusion in School of Business: Faculty Publications and Other Works by an authorized administrator of Loyola eCommons. For more information, please contact ecommons@luc.edu.

\section{(c) (1) $\Theta \Theta$}

This work is licensed under a Creative Commons Attribution-Noncommercial-No Derivative Works 3.0 License. Author Posting (c) American Marketing Association, 2016. 


\section{Authors}

Andres Barrios, Kristine de Valck, Clifford J. Shultz, Olivier Sibai, Katharina C. Husemann, Matthew Maxwell-Smith, and Marius K. Luedicke 


\title{
Marketing as a Means to Transformative Social Conflict Resolution: Lessons from Transitioning War Economies and the Colombian Coffee Marketing System
}

\author{
Andrés Barrios, Kristine de Valck, Clifford J. Shultz II, \\ Olivier Sibai, Katharina C. Husemann, Matthew Maxwell-Smith, \\ and Marius K. Luedicke
}

\begin{abstract}
Social conflicts are ubiquitous to the human condition and occur throughout markets, marketing processes, and marketing systems. When unchecked or unmitigated, social conflict can have devastating consequences for consumers, marketers, and societies, especially when conflict escalates to war. In this article, the authors offer a systemic analysis of the Colombian war economy, with its conflicted shadow and coping markets, to show how a growing network of fair-trade coffee actors has played a key role in transitioning the country's war economy into a peace economy. They particularly draw attention to the sources of conflict in this market and highlight four transition mechanisms-empowerment, communication, community building, and regulation - through which marketers can contribute to peacemaking and thus produce mutually beneficial outcomes for consumers and society. The article concludes with a discussion of implications for marketing theory, practice, and public policy.
\end{abstract}

Keywords: Colombia, peace/war economy, social conflict, systemic analysis, transformation

$\mathbf{F}$ rom the bazaars of ancient Mesopotamia to today's globalized economy, markets are spaces in which participants compete and cooperate to increase wealth and, ideally, wellbeing. While markets commonly operate as civilized competition, they also are sites for social conflict. Examples of the latter include territorial gang violence; personal vendettas; international patent violations and litigation; neighborhood disputes; exclusion, exploitation, and abuses throughout global supply chains; and, in worst-case scenarios, war, to name but a few dysfunctional and harmful market activities that can invoke or embody social conflicts.

Andrés Barrios is Assistant Professor, Universidad de Los Andes (e-mail: andr-bar@uniandes.edu.co). Kristine de Valck is Associate Professor of Marketing, HEC Paris (e-mail: devalck@hec.fr). Clifford J. Shultz I/ is Professor and Charles H. Kellstadt Chair of Marketing, Loyola University Chicago (e-mail: cjs2@luc.edu). Olivier Sibai is Lecturer in Marketing, Birkbeck, University of London (e-mail: o.sibai@bbk.ac.uk). Katharina C. Husemann is Lecturer in Marketing, Royal Holloway, University of London (e-mail: katharina.husemann@royalholloway.ac.uk). Matthew Maxwell-Smith is Postdoctoral Research Associate of Marketing, University of Illinois at Urbana-Champaign (e-mail: mmaxweluwo@illinois. edu). Marius K. Luedicke is Associate Professor of Marketing, Cass Business School, City University London (e-mail: m.luedicke@city.ac. uk). Julie Ozanne served as associate editor for this article.
Social conflicts occur when two or more parties pursue interests regarded as mutually interdependent and incompatible, such that the accomplishment of one party's goals comes at the expense of one or more other parties achieving their goals (e.g., Deutsch 1973, 2006; Marcus 2006; Ostrom et al. 2002). These conflicts comprise various elements, typically behaviors (actions meant to be hurtful), objects (the reasons to struggle), parties (agents engaging in conflict behaviors), intervenors (agents engaging in the conflict in an attempt to make, build, or keep peace), and stages (e.g., Jeong 2008; O'Gorman 2011).

These elements often interact simultaneously and operate at different levels: individual (micro), group (meso), and national and global (macro) (e.g., Ramsbotham, Woodhouse, and Miall 2011). At the individual level, social conflicts can elicit physical, emotional, and cognitive harm (Cummings et al. 2009; Haslam et al. 2009; Kessler, Mickelson, and Williams 1999; Lindner 2014; McMichael and Manderson 2004; Osborne and Sibley 2013; Pascoe and Richman 2009). At a group level, social conflicts influence how citizens treat each other, including what and whether they consume (Durvasula and Lysonski 2006; Ouellet 2007; Shimp and Sharma 1987), because they often produce more defensive and aggressive behaviors and thus dampen prosocial and cooperative behavior (De Dreu and Van Knippenberg 2005; Deutsch 2006). Defensive and aggressive conflicts often escalate into parties ostracizing, dehumanizing, discriminating, 
and overtly fighting against one another (Haslam 2006; Sherif 1966; Shultz et al. 2005; Struch and Schwartz 1989). At a national level, such violent social conflicts can interrupt or destroy key institutions; criminal behavior and commerce may dominate, which can lead to social disorder, chaos, and even government collapse and war (e.g., Jia, Karpen, and Hirt 2011; Kriesberg 2007).

Given the high stakes, complexity, reach, and existential threats of violent social conflicts, they (should) demand attention. The path to resolution, however, is often complicated because social conflict is typically intersectional, systemic, and multilayered; resolution must involve numerous players; institutions; and political, cultural, economic, and consumer forces. The purpose of this article therefore is to analyze how marketing can contribute to social conflict resolution and to develop a theory-based framework to understand the peacemaking role of marketing systems in contexts characterized by long-standing violent conflict and the dominance of war economies.

To contextualize our framework, we explore the Colombian coffee marketing system, which has been racked by violent conflict in the form of the world's longest civil war. We show how multistakeholder endeavors, as illustrated by an innovative fair-trade marketing initiative, have been crucial for attenuating or resolving long-lasting conflicts. By doing so, we demonstrate a powerful, transformative way to use markets for peacemaking and political, social, economic, and consumption change, consistent with seminal contributions in the literature on marketing systems (e.g., Baker et al. 2015; Coleman 2014; Fisk 1967; Fort and Schipani 2004; Hill and Martin 2014; Hunt 2010; Layton 2015; Oetzel et al. 2010; Shultz 2007; Viswanathan, Rosa, and Ruth 2010; Wilkie and Moore 1999). We conclude with a discussion of implications for theory development, marketing practice, public policy, and further research.

\section{Theoretical Foundations}

Review and distillation of a broad and varied literature reveals four grand schools of thought in conflict theory, with distinct assumptions on the nature of social conflict (O'Gorman 2011; see also Coleman, Deutsch, and Marcus 2014). The inherency school follows the Hobbesian notion that aggression is innate to the human condition as a result of biological (e.g., Wilson 2001) or cultural factors (e.g., Huntington 1993). For the structuralists, social conflict results from covert violence serving the interests of certain people and preventing others from reaching their potential (e.g., Galtung 1969; Marx and Engels [1848] 1969). The social-psychological school assumes that social conflict results from frustration and grievances derived from interpersonal and intergroup interactions (e.g., Dollard et al. 1939; Gurr 1970). The economic school suggests that social conflict is a means to allocate resources and/or to optimize utility for individuals, groups, or nations (Pruitt and Rubin 2004).

A social conflict can take many different forms depending on the context. Therefore, applied theories of conflict have developed, blending the four grand schools of thought to characterize the parties, objects, behaviors, levels, and dynamics of the conflict under study. For example, scholars have developed specific theories to characterize family conflict (Finkel et al. 2013), social media conflict (Husemann, Ladstaetter, and Luedicke 2015; Sibai et al. 2015), intergroup conflict (Maxwell-Smith et al. 2016), organizational conflict (Rahim 2002), social class conflict (Marx and Engels [1848] 1969), international conflict (Most and Starr 1983), and conflict in dynamic systems (Lewin [1948] 1997), including marketing systems (e.g., Fisk 1967; Hill and Martin 2014; Shultz 2007). Here, our interest lies in marketing systems fractured by civil wars - the preponderant form of internecine social conflict since the end of the Cold War (Elbadawi and Sambanis 2002; Pettersson and Wallensteen 2015; Shultz et al. 2005). Our purpose is to develop a theory-based framework that enables us to systematically analyze the role of macro-level marketing systems in transforming war economies into peace economies. In doing so, we complement extant literature on political solutions to peacemaking as well as studies that have taken a micro-level perspective on the role of individual businesses in market transformation.

In civil war, a dominant party is in control of the state or region, while a rebelling party aims to gain control. In the pursuit of maintaining or claiming power, the opposing parties draw on a variety of warfare means, such as guerrilla methods and extreme violence against civilians, that instill terror in the population; group affiliation typically stems from ethnic, political, religious, or tribal belonging (Kaldor 2013; Lieu and Opotow 2014). Therefore, civil wars are difficult to resolve and typically become protracted (Coleman 2014; Hegre and Sambanis 2006). When the war is prolonged, hostility between groups becomes less prevalent and self-reproducing war economies develop. Consequently, economic matters become a major driver in the perpetuation of war (Collier, Hoeffler, and Söderbom 2004; Keen 2000). In the following subsections, we discuss how war economies prevent the attainment of peace and how peacemaking efforts can help to achieve peace.

\section{War and Peace Economies, Policies, and Markets}

War economies are economic systems of production, mobilization, and allocation of resources developed in the context of conflicts involving violent and destructive engagements among militaries, paramilitaries, guerrillas, and civilian populations (Le Billon 2005). They are characterized by severe political, economic, and social inequalities (Stewart, Brown, and Langer 2008). Both a dysfunctional state and the market play a major role in maintaining a war economy and respective inequalities.

The state is dysfunctional to the extent that it fails to provide certain public goods required for societal well-being (Varian 1992). In particular, security manifested as physical safety, wealth, and welfare is limited to small segments of society typically affiliated with the ruling party or class (Stewart 2008). Security thus turns into a club of sorts, in which goods and services are accessible only to people who are members (Scotchmer 2008). In other words, the resources of the state are leveraged by those controlling it to serve private interests of a favored group. The state functions as a kleptocracy in which rulers manipulate formal government institutions to retain power, wealth, and economic actors to access markets (Reno 2000). That is, kleptocrats make fortunes working with local traders, intermediaries, business 
elites, foreign governments, and even adversaries (Gamba and Cornwell 2000). Because public services are privatized, economic, social, and political resources lack comprehensive redistribution; existing socioeconomic inequalities subsequently expand (Duffield 2000; Keen 2000).

Markets play a major role in sustaining war economies. War economy markets are criminalized and function outside the rule of law (Duffield 2000); Goodhand (2004) distinguishes three types. The first is a combat market, which mainly involves trade activities that directly fund the war effort. These activities include trade of money, arms, equipment, and fuel; taxation of licit and illicit economic activities; and economic blockades. Second, war economies develop shadow markets, which revolve around trade made by entrepreneurs on the margins of the conflict. Trade typically includes drug trafficking, smuggling, mass extraction of natural resources, currency exchange, and manipulation of aid resources. Coping markets, the third type, consist of the trade by which the majority of the population struggles to survive. Participants in this market either work in agriculture, petty trade, or small businesses or live on wage labor, remittances, redistribution through family resources, or humanitarian assistance.

As these market structures slowly emerge and stabilize during civil war, market actors become dependent on the continuation of war to sustain their livelihood. The actors of the combat market accumulate wealth from waging war, actors of the shadow market build entrepreneurial activities on the margin of it, and actors of the coping economy depend on the combat and shadow markets to eke out a living and reimburse their loans (e.g., Berdal and Malone 2000). Markets therefore produce short-term economic interests in perpetuating the war economy, making long-term dissolution and sustainable replacement extraordinarily difficult, if not impossible (Ostrom et al. 2002; Shultz and Holbrook 1999; Shultz 2015). Furthermore, the increasing destitution of the actors in the coping market nurtures grievances and discontent, fueling further violence and the war's continuation (Duffield 2000; Keen 2000).

In contrast to war economies, peace economies are stable economic systems of production, mobilization, and allocation of resources operating in environments bereft of violent and destructive activities executed by militaries, paramilitaries, and guerrillas (Goodhand 2004). Peace more simply is the "absence of violence" (Galtung 1969, p. 168), though it can comprise both "negative" and "positive" peace. Negative peace is the absence of direct personal violence, while positive peace is the absence of structural violence and the presence of conditions that allow social justice to emerge (Galtung 1969). Peace economies particularly strive to guard against structural violence and aim to suppress and/or bind political, economic, and social inequalities through constant adjustments and regulation (Richmond 2011; Stewart 2008).

The state and the market play key roles in perpetuating a peace economy and in limiting inequalities. The state, in forms of local and national institutions, typically develops a governance system that ensures the provision of human security to all members of society. Human security as a public good refers to freedom from physical and psychological harm, access to livelihood opportunities through education and welfare services, avoidance of social prejudices and discrimination, and the ability to politically participate in the enforcement and adaptation of the governance system (Goodhand 2006). Markets can contribute to the flourishing of peace economies by promoting and fostering constructive engagement to ensure mutually beneficial cooperation among the stakeholders of economies/systems, through access, inclusion, security, social justice, and sustainable prosperity (McMillan 2003; Shultz 2015).

\section{Peacemaking}

Peacemaking consists of all the initiatives geared toward resolving war and building positive sustainable peace (Goodhand 2006; Lederach 2003). The challenge of transforming a war economy into a peace economy involves reaching three peacemaking objectives (Barnett et al. 2007). The first objective is to undermine the actors of the war economy who threaten national security and challenge the legitimacy of the peace economy. After war, this typically involves discouraging former combatants from returning to war through disarmament, demobilization, and reintegration. The second objective focuses on restoring the legitimacy of the state as the provider of public goods. This involves development agencies and civil society organizations partnering with the state to rebuild facilities (utilities, transportation, and communication infrastructures), reestablish education and health services, rebuild capacity to run public administrations, and enforce the rule of law. The third objective consists of helping the actors of the war economy become meaningfully engaged with the peace economy. This approach involves, among other techniques, offering trauma counseling, enforcing transitional justice and reconciliation, and facilitating community dialogue. In summary, the different approaches to peacemaking focus on the creation of a governance system involving governmental, supragovernmental, and civil society actors to transform a war economy into a peace economy.

A wealth of literature exists on political solutions to peacemaking. In general, four types of political approaches to peacemaking are distinguished: from "above" or from "below" and from "outside-in" or "inside-out" (Goodhand 2006; Richmond 2011). Strategies from above suggest how political and military elites can settle the conflict, while strategies from below indicate how local communities, social movements, and nongovernmental organizations can contribute to resolution. Strategies from outside-in focus on how foreign governments and international nongovernmental organizations can promote the emergence of peace, while strategies from inside-out focus on how local governments and civil society organizations in the country can resolve the war by themselves.

Surprisingly, the literature on the role of markets in peacemaking is somewhat limited. In the past, market actors were overwhelmingly viewed as forces nurturing war (Haufler 2015). Large local businesses were considered pillars of the war economy (Duffield 2000; Keen 2000), with foreign businesses plundering local resources and profiting from the absence of a strong state-centered governance system (Hook and Ganguly 2000). Calls were made for social and political actors to control market actors, including the development of policies focused on "controlling the potential adverse social 
impact of business activity" (Ford 2015, p. 23). Trends in the past 15 years reveal that although firms can differ in both values and actions, when firms act more prosocially, their leaders and stakeholders tend to recognize both long- and short-term benefits, including a more positive environment in which to conduct business. Consequently, corporations in increasing numbers have served as potentially positive forces, which cannot be ignored in peacemaking (Forrer and Katsos 2015). For example, Ford (2015, p. 3) argues that "business people may have far more proximate and long-term personal and vested interests in building a deeper peace than transitory international peacebuilding officials." In addition, Kaldor (1999, p. 118) identifies business sites, such as plantations or large mines, as serving society as relative "islands of civility" in times of war. Business sites-and the marketing activities in them and in support of them-serve as spaces in which trust and hope can redevelop (Ford 2015). Considering businesses and marketing as instruments of peacemaking implies that they are not solely economic agents guided by profit; rather, they are policy agents or corporate diplomats, equally interested in promoting social wellbeing through the market (Westermann-Behaylo, Rehbein, and Fort 2015). As such, businesses may avoid activities that are profitable in the short run because, in doing so, they would contribute to conflict building in the long run and engage in unprofitable activities out of moral and political consciousness.

Both scholars (Westermann-Behaylo, Rehbein, and Fort 2015) and civil society institutions (Amis, Hodges, and Jeffery 2006; Nelson 2000; see also Baker et al. 2015; Laczniak and Murphy 2006; Santos and Laczniak 2011) have identified a large variety of political corporate social responsibility activities promoting peace. These activities range from conflict-sensitive business practices to avoid unintentional harm (e.g., no bribing) to proactive peacemaking initiatives involving the education of civil society (e.g., communicating about the benefits of a cease-fire for all) and lobbying of government agencies (e.g., demanding that the government enforce transparency in natural resource procurement). However, insights developed so far have focused on peacemaking initiatives at the micro level of individual businesses, moving in some cases to the meso level of partnerships between businesses and other market stakeholders, such as political agencies and community organizations.

At a macro level, the role of markets in peacemaking has remained undertheorized, and voices have called for research to fill this gap (Haufler 2015; Kolk and Lenfant 2015). Marketing scholars have highlighted that marketing systems are integral to war recovery and war prevention (e.g., Shultz 2007; Shultz et al. 2005). However, further research is required to theorize how marketing systems characteristics help an area move from a war economy to a peace economy. To illuminate the way in which marketing systems can contribute to a transition toward a peace economy, we use social conflict theory in the case of the fair-trade coffee marketing system in the Colombian civil war. From an analysis and synthesis of available literature, we describe four mechanisms through which marketing systems can contribute to peacemaking: (1) empowerment, or providing citizens with the necessary resources and capabilities to engage in cooperative/peaceful activities; (2) communication, or ensuring that all parties have opportunities to participate in and negotiate peace settlements that guarantee that the agreement is respected as well as to promote transparency, trust, and willingness to cooperate; (3) community building, or establishing and nurturing inclusive, representative grassroots groups, incentives, and organizations to legitimize the idea that collaborative choices are most beneficial for all stakeholders; and (4) regulation, or fostering consistent, fair, and equal enforcement of laws or the adoption of commercial governance procedures that affect people's perceptions about the risks and benefits of both types of economies.

\section{Systemic Analysis of the Colombian War Economy}

To develop a conceptualization of how demand-focused and market-based peacemaking initiatives can operate, we analyze the Colombian civil war as a living case. Colombia is known as a stable democracy with strong democratic institutions but is infamous for being home to the longest internal armed conflict in the world: its civil war has lasted 50 years, with $8,792,781$ people victimized $(1,525,529$ killed or missing, and 7,090,493 forcibly displaced; Registro Único de Víctimas 2015). The Colombian civil war exploded from social and political movements, but drug trafficking turned it into a war economy, and the conflict subsequently became protracted.

We develop a systemic analysis of the Colombian war to investigate how markets have contributed to peacemaking in this context. In particular, we analyze how the Colombian fair-trade coffee industry has contributed to countervail the negative effects of the civil war. Colombian coffee, with its renowned imagery and symbols (e.g., Juan Valdez) is a global product, recognized and valued around the world. Fair-trade markets and practices have emerged as economically viable, sustainable, and prosocial development initiatives because of their transformative potential for improving farmers' well-being (e.g., Raynolds and Bennett 2015).

\section{The Colombian Civil War}

The Colombian conflict began in the early 1960s. It embodied the political and socioeconomic differences evinced between the capitalist (right-wing) and communist (left-wing) ideologies of the Cold War. The intersections of these political elements with the income inequalities experienced by the people created several grievances that prompted the emergence of two communist-oriented movements: Fuerzas Armadas Revolucionarias de Colombia (FARC) and Ejército de Liberación Nacional (ELN). These movements initially rebelled against the central government for more social justice and changes to the existing social structure of the country (Ning 2005). The conflict was initially characterized as low-intensive warfare in a developing country (Rice 1988), and it remained in this condition for nearly two decades.

During the 1980s, the conflict drastically changed and escalated, fueled by guerrillas' exploitation of illegal businesses in the country (Ballentine and Nitzschke 2003). Guerrillas entered the growing narcotics industry through illegal taxation to narcotics producers and then became producers themselves. In addition, they extorted legal companies and kidnapped 
businesspeople. These activities provided FARC with approximately US $\$ 500$ million per year. The development of the cocaine industry transformed the grievance conflict into a commercial endeavor based on greed, which involved new actors. The right-wing paramilitary group Autodefensas Unidas de Colombia emerged as a new conflict party. This group consisted of mercenaries hired by drug dealers and large landowners to protect their businesses against the guerrillas.

According to Firchow (2005, p. 46), the Colombian conflict morphed again during the 1990s from an ideological war to a "new" economic war comprised of "a mixture of international drug trafficking, weapons, money-laundering, criminality and terrorism with international political and economic elements involved." The consequences of the economic war have been horrific, as victims were no longer limited to military forces in war zones. Terrorist attacks by both groups targeted civilians as well. According to the Colombian government, the war resulted in 486,232 victims before 1990, but the number of victims reached 6,902,398 (81.5\% civilians and $18.5 \%$ combatants) between 1990 and 2010. Colombia's overall economic development suffered concurrently. Losses from the conflict during the 1980s and 1990s have been estimated to be $4.5 \%$ of gross domestic product (Trujillo and Badel 1998), and foreign direct investment shrank by $40 \%$ (Ramirez and Duran 2015).

A brief overview of the Colombian civil war provides a glimpse of the different markets working in the war economy. First, the guerrillas and paramilitary groups developed the combat markets, using kidnapping, extortion, and illegal taxation to fund their war activities. Second, entrepreneurs, supported by the guerrillas and paramilitary groups, developed the shadow markets, engaging in different illegal market activities, including drug and human trafficking, informal gold mining, and money laundering. Third, the remaining members of society developed the coping markets; they struggled to develop their legal activities while dodging the combat and shadow markets to avoid confrontations with guerillas and paramilitaries.

\section{Political Peacemaking Initiatives in Colombia}

Since the beginning of the conflict, different Colombian governments have embarked on political attempts to reach peace agreements with the left-wing armed groups-in 1984 with FARC, 1994 with FARC and ELN together, and 1999 with FARC again. However, the war economy deeply embedded in the conflict, particularly drug trafficking, undermined these processes and prevented any successful peace agreements. At the start of the twenty-first century, the country developed and implemented an antidrug program "Plan Colombia," under which the United States and the European Union provided almost US $\$ 10$ billion. This program aimed to cut the financial resources of guerrillas and paramilitary groups by providing military and social aid to regions where drug trafficking was pervasive. Some results attributed to this program include the demobilization of the Autodefensas Unidas de Colombia paramilitary group in 2008 and the diminishment of the guerrillas' strength to the point at which they agreed, in 2012 FARC and in 2015 ELN, to start peace talks with the government (The Economist 2015)
After four years of negotiations (2012-2016), the country is close to a peace agreement with the left-wing guerrillas. This accord has enormous potential to stop the violence and boost economic and social development in the country (see The Economist 2015). However, much remains to be done to transform the war economy structures. Along with the peace agreement, the country needs the participation and cooperation of public and private sectors to create market-based initiatives and adaptations to break the inequalities that sparked the decades-old conflict. We turn our attention to this issue in the next subsection.

\section{Market-Based Peacemaking Actions: The Case of the Colombian Coffee Market}

The coffee industry has been an important source of income and a critical driver of Colombia's social development (Giovannucci 2003). Coffee arrived in what is now the country of Colombia with the Jesuits in 1730 (Federación Nacional de Cafeteros [FNC] 2015a) and is now one of the landmark products of the country. Colombia's geography, with 2,112 miles of mountain chains along the Andes, is particularly beneficial for coffee, which grows on the mountains' hillsides. Colombia is currently the world's third-largest coffee producer: more than 12 million coffee burlap bags, valued at US\$1.97 billion (FNC 2015b), are sold each year. The intensive labor required for coffee production in Colombia has a far-reaching social impact (Roldán-Pérez et al. 2009). Coffee regions are mainly located in poor rural areas, where government institutions do not efficiently reach. Agriculture and coffee harvesting have been a cultural tradition and the primary source of income. Coffee production provides jobs to more than 800,000 people, representing $32 \%$ of the agricultural employment in the country (FNC 2015c).

The Colombian war economy is fueled by the narcotics industry, particularly cocaine, which is cultivated in natural conditions similar to those required for coffee (Oxfam International 2002). Since the 1990s, cocaine and coffee production systems have intersected, resulting in several economic and social consequences. In 2014 Colombia had 936,682 hectares of coffee fields (FNC 2015a) and 69,132 hectares of cocaine fields (UNODC 2015). Figure 1 illustrates Colombian geographical intersection between the coffee fields (represented by solid lines) and the cocaine fields (represented by dashed lines), with the latter located near the country's borders for easier exportation. In the following subsections, we describe the coffee production system, identify the social problems caused by the intersection with the cocaine production system, and show how the fair-trade ${ }^{1}$ marketing system promotes peacemaking. Particularly, we describe how each peacemaking mechanism has promoted

\footnotetext{
1Several studies have discussed and debated the positive and negative aspects of the fair-trade movement. Some have criticized the ideological basis of using consumption to reduce consumption-related problems (Johnston 2002) or to maintain the imbalanced power relations between the Northern Hemisphere (consumers) and Southern Hemisphere (producers) (Lyon 2006). Others have favored fair-trade-expanded economic and social indicators, such as income, education, and health (Arnould, Plastina, and Ball 2009). In this research, we focus on the positive aspects of fair-trade markets as a vehicle for social and economic development.
} 
Figure 1. Colombia: Coffee-Growing Regions and Areas of Guerrilla Influence

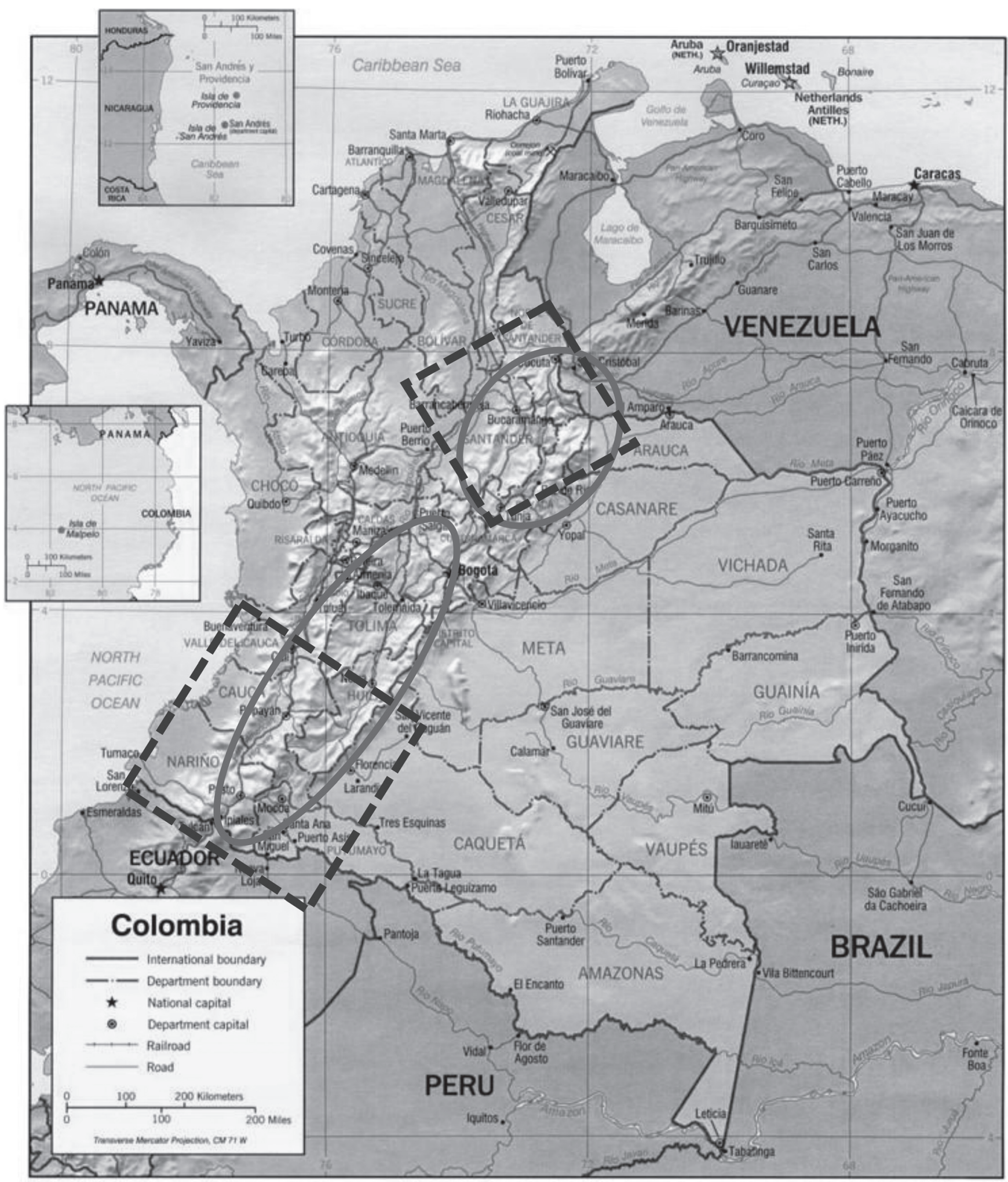

Base 802671AI (RODB20) 6.0: 
the peacemaking objectives presented in the "Theoretical Foundations" section. Among the different fair-trade market initiatives in the country, we focus on the one promoted by the FNC. The FNC is the largest Colombian semiprivate organization owned by coffee producers and financed by government taxation of coffee exports, whose objective is to improve farmers' quality of life (FNC 2015c). Today, the FNC represents more than 500,000 farmers in the country.

\section{Peacemaking Mechanism: Empowerment}

Production in the coffee marketing system begins on Colombian hillsides, where farmers harvest the crops with the help of their families on small parcels of land. These families have usually worked on these lands for generations without any official entitlement to the land. Because cocaine crops require soil characteristics similar to those needed for coffee crops, farmers were and continue to be frequently threatened or attacked by guerrillas and drug dealers who want access to the farmers' lands for cocaine production (Wilson 2001). Such violent actions have displaced many farmers from their homes and forced them to enter the coping market, while others have been forced to enter the shadow market by cooperating with the guerillas and sharing their profits from cocaine production. As a result, many farmers experience a lack of control over their lives and territory.

The FNC, with support of the government, has institutionalized land ownership by promoting the restitution of the displaced families' lands as well as by providing soft loans to farmers' families for land ownership. In the 1980s, the main coffee regions were located in the country's central zones such as Quindío and Risaralda; today, the southern regions that were traditionally dominated by guerrillas and paramilitary groups have again begun to produce coffee (e.g., departments of Cauca, Nariño, and Huila) (Biswas-Tortajada and Biswas 2015). By enabling farmers to take official ownership of their lands, the FNC has helped them take stewardship over the territory where they reside and provided them with a perspective of long-term stability (World Fair Trade Organization 2015). This has helped empower farmers to resist or exit the shadow market and to reintegrate into the peace economy.

\section{Peacemaking Mechanism: Communication}

Farmers' coffee production-to-harvest process involves planting seeds, removing weeds, and fertilizing plants, activities that require continuous quality water supply. However, cocaine production involves the use and contamination of available water sources (Dourojeanni 1992). In addition, the government's use of air-administered pesticides to dry the cocaine fields has contaminated the water, with irreversible impacts on the neighboring coffee crops and farmers' health (Vargas 2002). This situation has created a double-sided problem, generating disputes between coffee and cocaine farmers as well as between coffee farmers and the government. The ideological division between farmers who are part of the coping market of coffee production and farmers who are part of the shadow market of cocaine production has dissolved social ties, leading to exclusion and discrimination among community members that transcend the conflict itself and may become a challenge for the communities after the conflict
(United Nations Office on Drugs and Crime 2014). Furthermore, the harmful effect of government air-administered pesticides has provoked several lawsuits against the government (Sherret 2005), which has delegitimized its role as promoter of people's well-being.

Both issues have been addressed and improved through the FNC's development of coffee farmer cooperatives, in which democratic decision making is mandatory. Including farmers in these cooperatives resulted in farmers embracing the realities of social interdependence, such as communication and collaboration; participation has motivated farmers to reflect on their civic participation by resisting pressures to grow cocaine (Nicholls and Opal 2005), thereby weakening the shadow and combat markets.

Moreover, the FNC has given a collective and, thus, more powerful voice to farmer cooperatives to communicate and negotiate with the government about alternative ways of eradicating cocaine plantations. To support these discussions, the FNC has funded research on the effects of pesticides on the quality of the soil and on farmers' health. As a result, government agencies (e.g., United States Agency for International Development in cooperation with local Colombian agencies) have developed programs for implementing alternative practices to transform cocaine fields (e.g., manual eradication), rallying the collective help of farmers and former guerrilla combatants (Belgian Development Cooperation 2012). Through these programs, as well as new regulations limiting the use of pesticides, the government has regained the people's trust as a protector and provider of public goods.

\section{Peacemaking Mechanism: Community Building}

After the harvest ends, and before being exported, coffee undergoes an industrial process that includes depulping, drying, milling, and grading the beans according to exportquality standards. On most farms, this process occurs in a rudimentary way, as there are no developed production capabilities. Because of the intersection with cocaine production markets, private investments in many coffee regions have stalled, which limits farmers' ability to improve the quality and quantity of coffee production. As a result, many farmers have trouble reaching a minimum subsistence level, which in turn forces them to employ all family members (including women and children) as casual laborers under poor circumstances (World Fair Trade Organization 2015). This element creates a vicious cycle in which the dynamics of farmers' poverty limits their abilities to obtain the tools (e.g., education) that could help them escape poverty, exposing them to the dubious opportunities offered by shadow and combat markets (Becker 1968; Oetzel et al. 2010).

The fair-trade market promoted by the FNC has played an important role in overcoming this vicious cycle of poverty. The FNC has supported international companies such as Nestlé and Starbucks to invest in traditional guerrilla-dominated regions to develop fair-trade coffee markets. Together with these multinational corporations, coffee cooperatives have fostered the production of indigenous, sustainable, and fairtrade-certified coffee controlled by specific supervision systems (Fridell 2007). The certified system comes with educational programs that empower farmers through increased knowledge and expertise. In addition, processing 
facilities have been built and shared among members of the fair-trade farmer communities, which has improved farmers' work conditions. With better equipment, coffee quality and quantity have increased, resulting in positive effects on farmers' income levels (Biswas-Tortajada and Biswas 2015). In addition, coffee cooperatives decide on the allocation of the surplus economic benefits of their joint activity, including the provision of community services such as education and health care. This further contributes to community building, as both fair traders and non-fair traders gain from these benefits (see Arnould et al. 2009).

\section{Peacemaking Mechanism: Regulation}

In the final stage of the coffee production system, farmers sell their coffee to brokers. Suranovic (2015) describes the broker system as an hourglass, in which a large number of small coffee farmers at one end need to pass the product through a small number of intermediaries to reach a large number of consumers at the other end. This market concentration of intermediaries is a determinant in the low payment farmers receive for their product, which is estimated as no more than $10 \%$ of the coffee retail price (Fair Trade 2012), estimated at US\$1.15 per pound in 2015 (FNC 2015b).

Although the FNC is not a governmental agency and thus cannot enforce laws, its actions have promoted fair trade, commercial-governing rules that have been adopted by other industry stakeholders (Utting 2015). The FNC has become one of the brokers of Colombian fair-trade coffee, exporting $26 \%$ of Colombian coffee production and offering farmers a price $200 \%$ higher than regular brokers for traditional coffee (FNC 2013). This situation has influenced other brokers to develop self-regulated fair-trade practices so that they are also able to negotiate a higher market price (Biswas-Tortajada and Biswas 2015). The government has further supported these market initiatives by developing policies for promoting community cooperatives and fair-trade certifications (Ramirez and Marin 2013). These examples of fair-trade actions highlight ways the coffee marketing system can positively affect farmer's economic security while helping reintegrate actors from the shadow and combat markets.

Overall, our analysis of the fair-trade coffee marketing system in Colombia has revealed the mechanism through which marketing systems can (1) provide actors from the shadow market with resources and capabilities that facilitate their reintegration to the peace economy (individual empowerment), (2) promote communication between/among actors of the coping and shadow markets and government bodies to enhance the legitimacy of the state (communication), (3) foster the development of resourceful communities that incentivize actors from the coping and shadow markets to embrace the peace economy (community building), and (4) nurture governmental support of self-imposed market regulations that promote the view that prosperity can be attained through the peace economy and legitimize the state as a provider of public good (regulation).

\section{Discussion}

The marketing and public policy literature has shown how marketing strategies and marketing system evolutions can be catalysts for well-being (e.g., Baker et al. 2015; Fisk 1967;
Hill and Martin 2014; Layton 2015; Shultz 2007; Viswanathan, Rosa, and Ruth 2010; Wilkie and Moore 1999) by resolving various forms of social conflicts, including the commons dilemma (e.g., Shultz and Holbrook 1999) and situations in which adversaries are enmeshed in international conflict (Shultz et al. 2005). Our research contributes to this stream of literature by offering a theory-based framework that helps systematically analyze how marketing contributes to social conflict resolution.

We use social conflict theory as well as findings from the war- and peace-economy literature to identify the different markets that constitute a war economy: combat, shadow, and coping markets. We complement the literature review with peacemaking theories to develop a framework of marketbased transformation mechanisms to analyze marketing systems' peacemaking role in contexts characterized by long-standing violent conflict and the dominance of war economies. This framework suggests that markets can contribute to peacemaking by fostering (1) empowerment, (2) communication, (3) community building, and (4) regulation. We apply this framework to the complex marketing system of Colombian fair-trade coffee, developed by the FNC. This systemic analysis shows how the various interconnected initiatives of this organization and other actors-such as governments, farmers, former members of nefarious groups and clandestine businesses (e.g., guerillas and paramilitaries), legitimate local businesses, multinational corporations, and global consumers-have supported the process of transforming Colombia's war economy into a peace economy.

The fair-trade marketing system in Colombia has been able to reach the three objectives of peacemaking (Barnett et al. 2007). Fair trade has undermined the war economy by offering farmers a viable "way out" of the shadow market of cocaine production, thus eliminating an important source of income for guerillas and drug dealers. It has restored the legitimacy of the government as a provider of public good through the FNC's efforts in helping farmer cooperatives negotiate a switch from harmful to sustainable ways of cocaine crop destruction. The government has also regained trust as a supporter of fair trade by developing policies for certification as well as playing an important role in land restitution and ownership programs. Finally, the fair-trade cooperatives have given farmers a means to overcome the division and tensions between those working in the shadow market and those working in the coping market. Instead of focusing on ideological differences, farmers now focus on business collaboration that emphasizes solidarity and the rebuilding of trust.

Together, the market-based peace transformation activities have resulted in many positive outcomes that interact simultaneously and operate at individual (micro), group (meso), and national (macro) levels. At a micro level, farmers who had been forced by the guerillas to abandon their soil or work in shadow markets could return to coffee production to earn a regular income, which provided them with better access to education, health care, and investment loans. At a meso level, fair-trade markets fostered farmers' communities by providing shared processing facilities and implementing a democratic decision system for the allocation of the surplus economic benefits of their joint activity. These communities became farmers' collective voice to communicate with other 
stakeholders, such as the government, multinational corporations, and the guerillas. At a macro level, these successes spurred foreign investments in the Colombian coffee market under a new model in which international companies collaborate with the government to develop public goods and services to improve farmers' capabilities. Thus, the vicious cycle of war - and the economy that drives or thrives in it-is broken; prudent policy and prosocial marketing and consumption have transformed the war economy into a more transparent, inclusive, nonviolent, virtuous market-based peace economy.

\section{Implications for Public Policy}

The implications of this research for public policy are many, varied, and consistent with the charge for transformative consumer research. Scholarship emanating from the transformative consumer research movement, for example, has noted the importance of intersectionality for effective marketing and public policy. This hints at systemic understanding of complex marketing and policy environments, with many interdependent stakeholders that also are conflicted over one or more issues. Such an approach is paramount when conflicts are careening toward or mired in systemically wide and sustained violence in the form of war. The potential for violence is exacerbated when egregious inequities among stakeholders emerge and the potential catalytic actors in the marketing/ political system are unprepared or unwilling to redress them (see also Shultz et al. 2012). However, as the case of Colombia illustrates, unresolved wars eventually affect every sector and every demographic, costing societies dearly in conscience, blood, and treasure, despite rank profiteering directly from the war. This reality should portend quick responses and swift, inclusive, transparent, and equitable policies that enable the constituent components of the marketing system to render said system more equitable while delivering legal goods and services. However, the huge rewards of short-term gains for a few war profiteers often have tremendous long-term costs to a much larger group (e.g., Ostrom et al. 2002; Shultz and Holbrook 1999).

Despite this social trap (short-term war profiteering), the paths to the resolution of systemically wide, violent conflict are not complex or mysterious. The systems in which they occur, however, often are, which makes the conflict seem intractable. Thus, of particular importance is an empathic understanding and clear articulation of how inequities are experienced differently among the conflicted parties and across populations (Gopaldas 2013). For example, a coffee grower in Ethiopia does not face the same social problems and challenges as a Colombian grower. Therefore, while opportunities for some "good" marketing and policy approaches do exist (e.g., fair-trade markets), a one-size-fits-all strategy does not. Nevertheless, in either context-especially a complex and conflicted context-systemic analysis, intervention, and changes to policies and practices are indispensable for developing peacemaking market strategies.

Our analysis suggests that marketers and policy makers aiming to promote peace need to have an integrative view that considers the different intersecting factors for provoking or preventing cooperation and mutually beneficial engagement. That is, they need to understand the consequences of marketing actions for society and vice versa, help promote fair-functioning markets through cooperation among actors and well-being for all stakeholders, and develop the policies and incentives that integrate local and global elements of markets and broader marketing systems.

Traditional approaches to promote fair-functioning markets have been to develop market-based policy instruments, including marketing policies, using a distributive market perspective adjusting the costs and benefits of their members (Nason 1989). Examples include the conflict resolution models regarding distribution channels (Assael 1968) and fuel taxes to compensate environmental externalities (for a detailed discussion, see Ostrom et al. 2002). However, such policy approaches operate on the assumption of a perfect market, in which producers and consumers interact in a perfectly compatible way, which rarely, if ever, exists (Mason and Muller 2004). Consequently, although traditional marketbased policy initiatives may be effective in correcting market imperfections, they are not so effective in resolving social conflicts in complex and dysfunctional marketing systems such as those immersed in a war economy. Therefore, policies should be transparent, inclusive, and regularly assessed for efficacy, compliance, improvement, and, in failed cases, possible elimination (see Hill and Martin 2014; Osgood 1962; Shultz 2015; Wilkie and Moore 1999).

What should be clear is that market-based policies must be influenced by extant conflict theory, including theory from beyond marketing literature; we offer a synthesis in this article. Such intersectionality of disciplines can lead to an expanded theory and broader understanding of and relevance to social spaces in which conflicts arise and play out, with potentially harmful or beneficial outcomes beyond them. Furthermore, our study shows how an analytical framework based on social conflict, war/peace economy, and peacemaking literature streams can be applied to shed light on the complex, intersecting problems that arise for the most vulnerable people in a troubled context such as the Colombian war economy. We also show how market-based initiatives such as fair trade can transform communities by improving empowerment, communication, community building, and regulation. Thus, using a systemic view of the intersecting and interdependent dynamics of markets, marketing, policies, and consumers in transitioning war economies, we provide a different perspective to actualize and elucidate tools, including marketing-related tools, to manage unavoidable market conflicts and to mitigate or manage those that are predictable and perhaps even desirable.

\section{Conclusion}

Social conflict, particularly when it is violent and results in war, is one of the most pressing problems confronting individuals, communities, and nation-states. This article uses a systemic view to show how market-based initiatives, such as the fair-trade market developed by the FNC, can become a transformative practice offering farmers in war economies an opportunity to escape from the shadow markets and be part of a collaborative market structure geared toward improving their well-being.

We emphasize that fair trade is only one approach among multiple market-based approaches available to marketers and 
policy makers who seek peacemaking initiatives. Further research should investigate other effective strategies for peacemaking along the different phases of conflict. Markets could play a different role in the management of a violent conflict during the emergence of the conflict, versus when conflict has become protracted, or during postconflict reconstruction efforts. We invite marketing scholars to continue exploring conflict theory and the literature on war and peace economies to infuse research programs that can expand the understanding of market-based solutions to social conflict. Finally, we call for more systemic research programs that take a holistic approach to social conflict to develop appropriate - or mutually agreed-on and acceptablemarketing and policy recommendations on a truly transformative scale, which could drive prosocial marketing, policy, and consumer behavior at national, regional, and global levels.

\section{References}

Amis, L., A. Hodges, and N. Jeffery (2006), "Development, Peace and Human Rights in Colombia: A Business Agenda," report, International Business Leaders Forum.

Arnould, Eric J., Alejandro Plastina, and Dwayne Ball (2009), "Does Fair Trade Deliver on Its Core Value Proposition? Effects on Income, Educational Attainment, and Health in Three Countries," Journal of Public Policy \& Marketing, 28 (Fall), 186-201.

Assael, Henry (1968), "The Political Role of Trade Associations in Distributive Conflict Resolution,” Journal of Marketing, 32 (April), 21-28.

Baker, Stacey Menzel, Ronald Paul Hill, Courtney Nations Baker, and John Mittelstaedt (2015), "Improvisational Provisioning in Disaster: The Mechanisms and Meanings of Ad Hoc Marketing Exchange Systems in Community," Journal of Macromarketing, 35 (3), 334-52.

Ballentine, Karen and Heiko Nitzschke (2003), "Beyond Greed and Grievance: Policy Lessons from Studies in the Political Economy of Armed Conflict," in Security and Development: Investing in Peace and Prosperity, R. Picciotto and R. Weaving, eds. London: Routledge, 159-86.

Barnett, Michael, Hunjoon Kim, Madalene O'Donnell, and Laura Sieta (2007), "Peacebuilding: What Is in a Name?" Global Governance, 13 (1), 35-58.

Becker, Gary S. (1968), "Crime and Punishment: An Economic Approach," Journal of Political Economy, 76, 169-217.

Belgian Development Cooperation (2012), Fair Trade in War Zones. Brussels: Belgian Development Agency.

Berdal, Mats and David M. Malone (2000), "Introduction," in Greed and Grievance: Economic Agendas in Civil Wars, M. Berdal and D.M. Malone, eds. Boulder, CO: Lynne Rienner Publishers, 1-19.

Biswas-Tortajada, Andrea and Asit Biswas (2015), Sustainability in Coffee Production: Creating Shared Value Chains in Colombia. New York: Routledge.

Coleman, Peter (2014), "Intractable Conflict," in The Handbook of Conflict Resolution: Theory and Practice, 3rd ed., P. Coleman, M. Deutsch, and E. Marcus, eds. San Francisco: Jossey-Bass, 708-43.

- Morton Deutsch, and Eric Marcus (2014), The Handbook of Conflict Resolution: Theory and Practice, 3rd ed. San Francisco: Jossey-Bass.
Collier, Paul, Anke Hoeffler, and Måns Söderbom (2004), "On the Duration of Civil War," Journal of Peace Research, 41 (3), 253-73.

Cummings, E. Mark, Marcie C. Goeke-Morey, Alice C. Schermerhorn, Christine E. Merrilees, and Ed Cairns (2009), "Children and Political Violence from a Social Ecological Perspective: Implications from Research on Children and Families in Northern Ireland," Clinical Child and Family Psychology Review, 12 (1), $16-38$.

De Dreu, Carsten K.W. and Daan van Knippenberg (2005), "The Possessive Self as a Barrier to Conflict Resolution: Effects of Mere Ownership, Process Accountability, and Self-Concept Clarity on Competitive Cognitions and Behavior," Journal of Personality and Social Psychology, 89 (3), 345-57.

Deutsch, Morton (1973), The Resolution of Conflict: Constructive and Destructive Processes. New Haven, CT: Yale University Press.

(2006), "Cooperation and Competition," in The Handbook of Conflict Resolution: Theory and Practice, M. Deutsch, P. Coleman and E. Marcus, eds. Hoboken, NJ: John Wiley \& Sons, 23-42.

Dollard, John, Neal E. Miller, Leonard W. Doob, Orval Hobart Mowrer, and Robert R. Sears (1939), Frustration and Aggression. New Haven, CT: Yale University Press.

Dourojeanni, M. (1992), "Environmental Impact of Coca Cultivation and Cocaine Production in the Amazon Region of Peru," research report, (accessed September 15, 2015), [available at http://www.unodc.org/unodc/en/data-and-analysis/bulletin/ bulletin_1992-01-01_2_page006.html].

Duffield, Mark (2000), "Globalization, Transborder Trade, and War Economies," in Greed and Grievance: Economic Agendas in Civil Wars, M. Berdal and D.M. Malone, eds. Boulder, CO: Lynne Rienner Publishers, 69-91.

Durvasula, Srinivas and Steven Lysonski (2006), "Impedance to Globalization: The Impact of Economic Threat and Ethnocentrism," Journal of Global Marketing, 19, 9-32.

The Economist (2015), “A Tale of Three Countries," Special Report: Colombia, (October 31), [available at http://www.economist. com/news/special-report/21676959-security-and-developmentare-crucial-achieving-peace-ground-tale-three].

Elbadawi, Ibrahim and Nicholas Sambanis (2002), "How Much War Will We See? Explaining the Prevalence of Civil Wars," Journal of Conflict Resolution, 46 (3), 307-34.

Fair Trade (2012), "Commodity Briefing," research report, (May), (accessed September 15, 2015), [available at http://www.fairtrade. net/fileadmin/user_upload/content/2009/resources/2012_Fairtrade_ and_coffee_Briefing.pdf].

Finkel, Eli J., Erica B. Slotter, Laura B. Luchies, Gregory M. Walton, and James J. Gross (2013), "A Brief Intervention to Promote Conflict Reappraisal Preserves Marital Quality over Time," Psychological Science, 24 (8), 1595-601.

Firchow, Pamina Maria (2005), “New' War Theory: Does the Case of Colombia Apply?" Peace, Conflict and Development: An Interdisciplinary Journal, 7 (July), 32-58.

Fisk, George (1967), Marketing Systems: An Introductory Analysis. New York: Harper and Row.

FNC (2013), "Comportamiento de la Industria Cafetera Colombiana," research report, (accessed September 15, 2015), [available at https://www.federaciondecafeteros.org/static/files/Informe_ Industrial_2013_Web.pdf]. 
(2015a), “A Beautiful Story,” (October 23), (accessed September 15, 2015), [available at http://www.cafedecolombia. com/particulares/en/el_cafe_de_colombia/una_bonita_historia/].

(2015b), “Colombian Coffee Insider,” (November 5), (accessed September 15, 2015), [available at http://www. federaciondecafeteros.org/algrano-fnc-en/].

(2015c), "Who Are We?" (November 5), (accessed September 15, 2015), [available at http://www.federaciondecafeteros. org/particulares/en/quienes_somos].

Ford, Jolyon (2015), Regulating Business for Peace. New York: Cambridge University Press.

Forrer, John J. and John E. Katsos (2015), "Business and Peace in the Buffer Condition," Academy of Management Perspectives, 29 (4), 438-50.

Fort, Timothy L. and Cindy A. Schipani (2004), The Role of Business in Fostering Peaceful Societies. Cambridge, UK: Cambridge University Press.

Fridell, Gavin (2007), Fair Trade Coffee: The Prospects and Pitfalls of Market-Driven Social Justice. Toronto: University of Toronto Press.

Galtung, Johan (1969), "Violence, Peace, and Peace Research," Journal of Peace Research, 6 (3), 167-91.

Gamba, Virginia and Richard Cornwell (2000), "Arms, Elites, and Resources in the Angolan Civil War," in Greed and Grievance: Economic Agendas in Civil Wars, M. Berdal and D.M. Malone, eds. Boulder, CO: Lynne Rienner Publishers.

Giovannucci, Daniele (2003), "Coffee," in Colombia: The Economic Foundation of Peace, M. Giugale, O. Lafourcade, and C. Luff, eds. Washington, DC: The World Bank, 517-24.

Goodhand, Jonathan (2004), "From War Economy to Peace Economy? Reconstruction and State Building in Afghanistan," Journal of International Affairs, 58 (1), 155-74.

(2006), Aiding Peace? The Role of NGOs in Armed Conflict. Boulder, CO: Lynne Rienner Publishers.

Gopaldas, Ahir (2013), “Intersectionality 101," Journal of Public Policy \& Marketing, 32 (Special Issue), 90-94.

Gurr, Ted R. (1970), Why Men Rebel. Princeton, NJ: Princeton University Press.

Haslam, Nick (2006), "Dehumanization: An Integrative Review," Personality and Social Psychology Review, 10 (3), 252-64.

Haslam, S. Alexander, Jolanda Jetten, Tom Postmes, and Catherine Haslam (2009), "Social Identity, Health and Wellbeing: An Emerging Agenda for Applied Psychology," Applied Psychology: An Interdisciplinary Review, 58 (1), 1-23.

Haufler, Virginia (2015), "Shaming the Shameless? Campaigning Against Corporations," in The Politics of Leverage in International Relations, R. Friman, ed. Hampshire, UK: Palgrave Macmillan, 185-200.

Hegre, Håvard and Nicholas Sambanis (2006), "Sensitivity Analysis of Empirical Results on Civil War Onset," Journal of Conflict Resolution, 50 (4), 508-35.

Hill, Ronald Paul and Kelly D. Martin (2014), "Broadening the Paradigm of Marketing as Exchange: A Public Policy and Marketing Perspective," Journal of Public Policy \& Marketing, 33 (Spring), 17-33.

Hook, Jacob and Rajat Ganguly (2000), "Multinational Corporations and Ethnic Conflict: Theory and Experience," Nationalism \& Ethnic Politics, 6 (1), 48-71.
Hunt, Shelby (2010), Marketing Theory: Foundations, Controversy, Strategy, Resource-advantage Theory. Armonk, NY: M.E. Sharpe.

Huntington, Samuel P. (1993), "The Clash of Civilizations?" Foreign Affairs, 72 (3), 22-49.

Husemann, Katharina C., Florian Ladstaetter, and Marius K. Luedicke (2015), "Conflict Culture and Conflict Management in Consumption Communities," Psychology and Marketing, 32 (3), 265-84.

Jeong, Ho-Won (2008), Understanding Conflict and Conflict Analysis. London: Sage Publications.

Jia, Lile, Samuel C. Karpen, and Edward R. Hirt (2011), "Beyond Anti-Muslim Sentiment: Opposing the Ground Zero Mosque as a Means to Pursuing a Stronger America," Psychological Science, 22 (10), 1327-35.

Johnston, Josée (2002), "Consuming Social Justice: Fair Trade Shopping and Alternative Development," in Protest and Globalisation: Prospects for Transitional Solidarity, J. Goodman, ed. Annandale, Australia: Pluto Press, 35-56.

Kaldor, Mary (1999), New and Old Wars: Organised Violence in a Global Era. Cambridge, UK: Polity Press.

(2013), "In Defence of New Wars," Stability: International Journal of Security and Development, 2 (1), 1-16.

Keen, David (2000), "Incentives and Disincentives for Violence," in Greed and Grievance: Economic Agendas in Civil Wars, M. Berdal and D.M. Malone, eds. Boulder, CO: Lynne Rienner Publishers, 19-42.

Kessler, Ronald C., Kristin D. Mickelson, and David R. Williams (1999), "The Prevalence, Distribution, and Mental Health Correlates of Perceived Discrimination in the United States," Journal of Health and Social Behavior, 40 (3), 208-30.

Kolk, Ans and François Lenfant (2015), "Cross-Sector Collaboration, Institutional Gaps, and Fragility: The Role of Social Innovation Partnerships in a Conflict-Affected Region," Journal of Public Policy \& Marketing, 34 (Fall), 287-303.

Kriesberg, Louis (2007), Constructive Conflicts. Oxford, UK: Rowman \& Littlefield Publishers.

Laczniak, Gene and Patrick Murphy (2006), "Normative Perspectives for Ethical and Socially Responsible Marketing," Journal of Macromarketing, 26 (2), 154-77.

Layton, Roger A. (2015), "Formation, Growth, and Adaptive Change in Marketing Systems," Journal of Macromarketing, 35 (3), 302-19.

Le Billon, Philippe (2005), Geopolitics of Resource Wars: Resource Dependence, Governance and Violence. London: Frank Cass.

Lederach, John P. (2003), The Little Book of Conflict Transformation. Intercourse, PA: Good Books.

Lewin, Kurt ([1948] 1997), Resolving Social Conflicts and Field Theory in Social Science, G.W. Lewin, ed. Washington, DC: American Psychological Association.

Lieu, Wen and Susan Opotow (2014), "Aggression and Violence: Causes and Correctives," in The Handbook of Conflict Resolution: Theory and Practice, 3rd ed., P. Coleman, M. Deutsch and E. Marcus, eds. San Francisco: Jossey-Bass, 681-707.

Lindner, Evelin G. (2014), "Emotion and Conflict: Why It Is Important to Understand How Emotions Affect Conflict and How Conflict Affects Emotions," in The Handbook of Conflict Resolution: Theory and Practice, 3rd ed., Peter Coleman, Morton 
Deutsch, and Eric Marcus, eds. San Francisco: John Wiley \& Sons, 283-309.

Lyon, Sarah (2006), "Evaluating Fair Trade Consumption: Politics, Desfetishization and Producer Participation," Journal of Consumer Studies, 30 (5), 452-64.

Marcus, Eric C. (2006), "Change in Conflict: Motivation, Resistance and Commitment," in The Handbook of Conflict Resolution: Theory and Practice, M. Deutsch, P.T. Coleman, and E.C. Marcus, eds. Hoboken, NJ: John Wiley \& Sons, 436-54.

Marx, Karl and Friedrich Engels ([1848] 1969), Manifesto of the Community Party. Moscow: Progress Publishers.

Mason, Simon A. and Adrian Muller (2004), “Analyzing Economic Market Interactions as Conflicts: New Concepts to Assess Market-Based Policy Instruments," Ecological Economics, 61 (1), 81-90.

Maxwell-Smith, Matthew A., Kelly L. Barnes, Joshua D. Wright, Clint Thomson, Megan A. Mattos, and Tara M. Dumas (2016), "Competition and Intergroup Bias: Toward a New Model of Distinguishing Competitive Perceptions from Competitive Motivations," Group Processes \& Intergroup Relations, (published electronically April 21), [DOI: 10.1177/1368430216642027].

McMichael, Celia and Lenore Manderson (2004), "Somali Women and Well-Being: Social Networks and Social Capital Among Immigrant Women in Australia," Human Organization, 63 (1), 88-99.

McMillan, John (2003), Reinventing the Bazaar: The Natural History of Markets. New York: Norton.

Most, Benjamin A. and Harvey Starr (1983), "Conceptualizing 'War': Consequences for Theory and Research," Journal of Conflict Resolution, 27 (1), 137-59.

Nason, Roger W. (1989), "The Social Consequences of Marketing: Macromarketing and Public Policy," Journal of Public Policy \& Marketing, 8, 242-51.

Nelson, Jane (2000), The Business of Peace: The Private Sector as a Partner in Conflict Prevention and Resolution. London: International Alert.

Nicholls, Alex and Charlotte Opal (2005), Fair Trade: MarketDriven Ethical Consumption. London: Sage Publications.

Ning, Travis (2005), "Colombia," in Human Rights and the War on Terror, J. Donnelly, ed. Denver: University of Denver, 83-102.

Oetzel, Jennifer, Michelle Westermann-Behaylo, Charles Koerber, Timothy L. Fort, and Jorge Rivera (2010), "Business and Peace: Sketching the Terrain," Journal of Business Ethics, 89, 357-73.

O'Gorman, Eleanor (2011), Conflict and Development: Development Matters. London: Zed Books.

Osborne, Danny and Chris G. Sibley (2013), "Through RoseColored Glasses: System-Justifying Beliefs Dampen the Effects of Relative Deprivation on Wellbeing and Political Motivation," Personality and Social Psychology Bulletin, 39 (1), 991-1004.

Osgood, Charles E. (1962), An Alternative to War or Surrender. Urbana: University of Illinois Press.

Ostrom, Elinor, Thomas Dietz, Nives Dolšak, Paul C. Stern, Susan Stonich, and Elke U. Weber, eds. (2002), The Drama of the Commons. Washington, DC: National Academy Press.

Ouellet, Jean-François (2007), “Consumer Racism and Its Effects on Domestic Cross-Ethnic Product Purchase: An Empirical Test in the United States, Canada, and France," Journal of Marketing, 71 (January), 113-28.
Oxfam International (2002), The Coffee Chain Game: An Activity on Trade for Ages 13 and Above. Oxford, UK: Oxfam.

Pascoe, Elizabeth A. and Laura Smart Richman (2009), "Perceived Discrimination and Health: A Meta-Analytic Review," Psychological Bulletin, 135 (4), 531-54.

Pettersson, Therése and Peter Wallensteen (2015), "Armed Conflicts, 1946-2014," Journal of Peace Research, 52 (4), 535-50.

Pruitt, Dean G. and Jeffrey Z. Rubin (2004), "The Structural Change Model," in Social Conflict: Escalation, Stalemate, and Settlement, D.G. Pruitt and S.H. Kim, eds. New York: McGraw-Hill Higher Education, 101-21.

Rahim, Afzalur (2002), "Toward a Theory of Managing Organizational Conflict," International Journal of Conflict Management, 13 (3), 206-35.

Ramirez, Gonzalo and Erli Marin (2013), Comercio Justo Globalización y Medio Ambiente. Bogota: Universidad Externado de Colombia.

Ramirez, Juliana and Paulo Duran (2015), "Reducción de la violencia en $40 \%$ atraería más inversión extranjera," (accessed September 15, 2015), [available at http://www.larepublica.co/ reducci\%C3\%B3n-de-la-violencia-en-40-atraer\%C3\%ADa-m\% C3\%A1s-inversi\%C3\%B3n-extranjera_228136].

Ramsbotham, Olivier Peter, Thomas Woodhouse, and Hugh Miall (2011), Contemporary Conflict Resolution. Cambridge, UK: Polity Press.

Raynolds, Laura and Elizabeth Bennett (2015), Handbook of Research on Fair Trade. Cheltenham, UK: Edward Elgar Publishing.

Registro Único de Víctimas (2015), "Reporte General," (accessed December 29, 2015), [available at http://rni.unidadvictimas.gov. $\mathrm{co} / ? \mathrm{q}=$ node/107].

Reno, William (2000), "Shadow States and the Political Economy of Civil Wars," in Greed and Grievance: Economic Agendas in Civil Wars, M. Berdal and D.M. Malone, eds. Boulder, CO: Lynne Rienner Publishers, 43-69.

Rice, Edward (1988), Wars of the Third Kind: Conflict in Underdeveloped Countries. Berkeley: University of California Press.

Richmond, Oliver P. (2011), A Post-Liberal Peace. New York: Routledge.

Roldán-Pérez, Adriana, Maria-Alejandra Gonzalez-Perez, Pham Thu Huong, and Dao Ngoc Tien (2009), Coffee, Cooperation and Competition: A Comparative Study of Colombia and Vietnam. Medellin, Colombia: UNCTAD Virtual Institute.

Santos, Nicholas and Gene Laczniak (2011), "Marketing to the Poor: An Integrative Justice Model for Engaging Impoverished Market Segments," Journal of Public Policy \& Marketing, 28 (Spring), 3-15.

Scotchmer, Suzanne (2008), "Clubs," in The New Palgrave Dictionary of Economics, 2nd ed., Steven N. Durlauf and Lawrence E. Blume, eds. Basingstoke, UK: Palgrave Macmillan.

Sherret, Laurel (2005), "Futility in Action: Coca Fumigation in Colombia," Journal of Drug Issues, 35 (1), 151-68.

Sherif, Muzafer (1966), Group Conflict and Co-Operation: Their Social Psychology. London: Routledge \& Kegan Paul.

Shimp, Terence A. and Subhash Sharma (1987), "Consumer Ethnocentrism: Construction and Validation of the CETSCALE," Journal of Marketing Research, 24 (February), 280-89. 
Shultz, Clifford (2007), "Marketing as Constructive Engagement," Journal of Public Policy \& Marketing, 26 (Fall), 293-301.

(2015), "The Ethical Imperative of Constructive Engagement in a World Confounded by the Commons Dilemma, Social Traps, and Geopolitical Conflicts," in Handbook on Ethics in Marketing, A. Nill, ed. Northampton, MA: Edward Elgar, 188-219.

Timothy J. Burkink, Bruno Grbac, and Nataša Renko (2005), "When Policies and Marketing Systems Explode: An Assessment of Food Marketing in the War-Ravaged Balkans and Implications for Recovery, Sustainable Peace, and Prosperity," Journal of Public Policy \& Marketing, 24 (Spring), 24-37.

Rohit Deshpandé, T. Bettina Cornwell, Ahmet Ekici, Prabakar Kothandaraman, Mark Peterson, et al. (2012), "Marketing and Public Policy: Transformative Research in Developing Markets," Journal of Public Policy \& Marketing, 31 (Fall), 178-84.

and Morris B. Holbrook (1999), "Marketing and the Tragedy of the Commons: A Synthesis, Commentary, and Analysis for Action," Journal of Public Policy \& Marketing, 18 (Fall), 218-29.

Sibai, Olivier, Kristine de Valck, Andrew Farrell, and John Rudd (2015), "Keyboard Warriors in Cyberfights: Conflict in Online Communities of Consumption and Its Effects on Community Resources," in Advances in Consumer Research, Vol. 42, June Cotte and Stacy Wood, eds. Duluth, MN: Association for Consumer Research, 685-86.

Stewart, Frances (2008), Horizontal Inequalities and Conflict: Understanding Group Violence in Multiethnic Societies. London: Palgrave.

Graham K. Brown, and Arnim Langer (2008), "Policies Towards Horizontal Inequalities," in Horizontal Inequalities and Conflict: Understanding Group Violence in Multiethnic Societies, F. Stewart, ed. Basingstoke, UK: Palgrave Macmillan.

Struch, Naomi and Shalom H. Schwartz (1989), "Intergroup Aggression: Its Predictors and Distinctness from Ingroup Bias," Journal of Personality and Social Psychology, 56, 364-73.
Suranovic, Steven (2015), "The Meaning of Fair Trade," in Handbook of Research on Fair Trade, L. Raynolds and E. Bennett, eds. Cheltenham, UK: Edward Elgar Publishing.

Trujillo, Ciro and Martha Badel (1998), Los costos económicos de la criminalidad y la violencia en Colombia: 1991-1996. Bogota: Departamento Nacional de Planeación.

United Nations Office on Drugs and Crime (2015), "Colombia Coca Cultivation Survey 2014,” (accessed July 15, 2016), [https:// www.unodc.org/documents/crop-monitoring/Colombia/Colombia Monitoreo_de_Cultivos_de_Coca_2014_web.pdf].

Utting, Peter (2015), "Corporate Accountability, Fair Trade and Multi-Stakeholder Regulation," in Handbook of Research on Fair Trade, L. Raynolds and Elizabeth Benett, eds. Chetelham, UK: Edward Elgar Publishing.

Vargas, Ricardo (2002), "The Anti-Drug Policy, Aerial Spraying of Illicit Crops and Their Social, Environmental and Political Impacts in Colombia," Journal of Drug Issues, 32 (1), 11-60.

Varian, H.R. (1992), Micro-Economic Analysis, 3rd ed. London: Norton \& Company.

Viswanathan, Madhu, José Antonio Rosa, and Julie A. Ruth (2010), "Exchanges in Marketing Systems: The Case of Subsistence Consumer-Merchants in Chennai, India," Journal of Marketing, 74 (May), 1-17.

Westermann-Behaylo, Michelle K., Kathleen Rehbein, and Timothy Fort (2015), "Enhancing the Concept of Corporate Diplomacy: Encompassing Political Corporate Social Responsibility, International Relations, and Peace Through Commerce," Academy of Management Perspectives, 29 (4), 387-404.

Wilkie, William and Elizabeth S. Moore (1999), "Marketing's Contributions to Society," Journal of Marketing, 63 (Special Issue), 198-218.

Wilson, Scott (2001), “Coca Invades Colombia's Coffee Field: Falling Prices Push Farmers to Plant Illegal Crops, Threatening U.S. Drug War," The Washington Post, (October 30), A17.

World Fair Trade Organization (2015), "10 Principles of Fair Trade," (accessed January 15 2016), [available at http://wfto.com/ fair-trade/10-principles-fair-trade]. 
Copyright of Journal of Public Policy \& Marketing is the property of American Marketing Association and its content may not be copied or emailed to multiple sites or posted to a listserv without the copyright holder's express written permission. However, users may print, download, or email articles for individual use. 